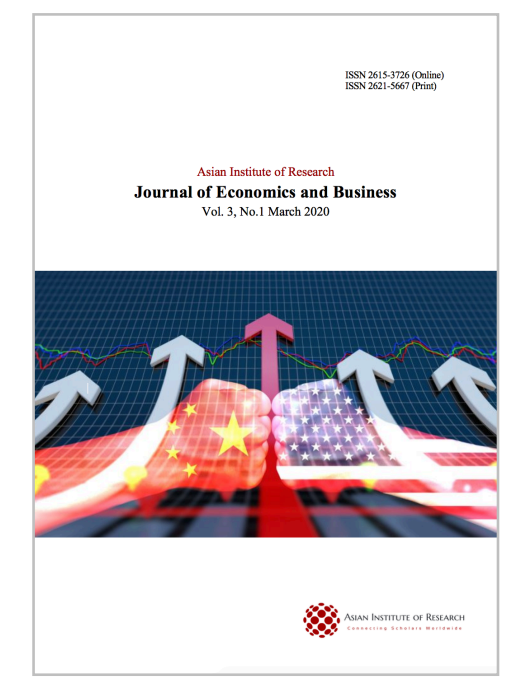

Journal of Economics and Business

Arsew, Viviana Tantiara, Kisman, Zainul, and Sawitri, Ni Nyoman. (2020), Analysis of the Effect of Loan to Deposit Ratio, Non-Performing Loans and Capital Adequacy Ratio on Return on Assets with Good Corporate Governance as Intervening Variable in Banking Companies Listed in the Corporate Governance Perception Index (CGPI) for the Period 2014 - 2018. In: Journal of Economics and Business, Vol.3, No.1, 115-130.

ISSN 2615-3726

DOI: 10.31014/aior.1992.03.01.182

The online version of this article can be found at:

https://www.asianinstituteofresearch.org/

Published by:

The Asian Institute of Research

The Journal of Economics and Business is an Open Access publication. It may be read, copied, and distributed free of charge according to the conditions of the Creative Commons Attribution 4.0 International license.

The Asian Institute of Research Journal of Economics and Business is a peer-reviewed International Journal. The journal covers scholarly articles in the fields of Economics and Business, which includes, but not limited to, Business Economics (Micro and Macro), Finance, Management, Marketing, Business Law, Entrepreneurship, Behavioral and Health Economics, Government Taxation and Regulations, Financial Markets, International Economics, Investment, and Economic Development. As the journal is Open Access, it ensures high visibility and the increase of citations for all research articles published. The Journal of Economics and Business aims to facilitate scholarly work on recent theoretical and practical aspects of Economics and Business. 
The Asian Institute of Research Journal of Economics and Business Vol.3, No.1, 2020: 115-130 ISSN 2615-3726

\title{
Analysis of the Effect of Loan to Deposit Ratio, Non- Performing Loans and Capital Adequacy Ratio on Return on Assets with Good Corporate Governance as Intervening Variable in Banking Companies Listed in the Corporate
} Governance Perception Index (CGPI) for the Period 2014 2018

Viviana Tantiara Arsew ${ }^{1}$, Zainul kisman ${ }^{1}$, Ni Nyoman Sawitri ${ }^{1}$

${ }^{1}$ Universitas Trilogi, Indonesia

\begin{abstract}
The purpose of this study was to examine the effect of loan to deposit ratio (LDR), non-performing loans (NPL), and capital adequacy ratio (CAR) on return on assets (ROA) in banking companies listed on the Indonesian Institute for Corporate Governance (IICG) in 2014-2018. This study uses Good Corporate Governance (GCG) as an Intervening variable. The use of intervening variables GCG in this study is a recent breakthrough in increasing return on assets. The sampling technique is purposive sampling. With this sampling method, the samples used in the study were 10 of the best banking companies implementing Good Corporate Governance registered in The Indonesian Institute for Corporate Governance (IICG) in 2014-2018. This study uses secondary data obtained from SWA Magazine publications. The analysis technique used in this study is path analysis. The results of the first structural equation model that LDR and NPL have a significant negative effect on GCG and CAR has a positive significant effect. The results of the second structural equation model that NPL, CAR, GCG have an influence on ROA, but LDR does not have a significant effect. The implication of this research is that GCG as a very large variable intervening plays a role in banks in increasing ROA.
\end{abstract}

Keywords: Loan to Deposit Ratio, Non-Performing Loans, Capital Adequacy Ratio, Return on Assets, Good Corporate Governance

\section{INTRODUCTION}

\section{I.1. Introduction and research rationale}

The development of banking that is increasingly rapid at this time leads to increasingly fierce bank competition. As a financial institution that plays an important role in supporting the economy in Indonesia, banks face 
increasingly complex risks and challenges. The risks and challenges faced by the bank are internal and external. Challenges from internal banks originate from the management of the bank itself, while external challenges from banks can originate from the economic conditions of a country where the bank operates. In addition, the condition of the country's economy which is the parent of foreign banks operating in Indonesia is also a challenge for banks. There are risks and challenges faced by banks, it is necessary to carry out an assessment related to the soundness of commercial banks in Indonesia. This assessment is intended so that commercial banks in Indonesia can survive in facing increasingly complex challenges and risks. Rating of the soundness of commercial banks is regulated in Bank Indonesia Regulation Number 13/1 / PBI / 2011 concerning Rating of Soundness of Commercial Banks. The assessment includes the integration of the bank's risk profile, Good Corporate Governance (GCG), profitability, and bank capital.

Liquidity is the company's ability to meet short-term obligations. These capabilities include the ability to provide funds when a customer requires withdrawal of deposit funds, the ability to provide funds when meeting credit requests without any delay, and the ability of a bank to maintain operational conditions in order to remain liquid (Fahmi, 2014: 117). The higher this ratio, the lower the liquidity of the bank concerned.

Financial ratios that can be used to measure credit risk are Non Performing Loans (NPL), this ratio measures the ability of banks to minimize the problem loans they face (Puspitasari, 2009).

Capital Adequacy Ratio (CAR) is a benchmark assessment of capital ratios in the context of the soundness of each bank. Capital adequacy is how a bank is able to finance its activities with capital ownership, in other words, CAR is used to measure the capital adequacy of banks to support assets that contain or generate risk, for example by granting credit to customers (Fahmi, 2014: 181 ).

Return On Assets (ROA) is a ratio used to show a company's ability to generate profits using total assets.

The following is empirical data about the variables used in this study, namely: loan to deposit ratio, non-performing loans, and capital adequacy ratio, return on assets (ROA) and good corporate governance. The selected sample is a banking company registered with the Indonesia Institute for Corporate Governance (IICG). Can be seen in Table 1.1 as follows :

Tabel 1: Average Banking Financial Ratios registered at The Indonesian Institute for Corporate Governance (IICG) in 2014-2018.

\begin{tabular}{|l|l|l|l|l|l|}
\hline \multirow{2}{*}{ Variable } & \multicolumn{5}{|c|}{ Years } \\
\cline { 2 - 6 } & $\mathbf{2 0 1 4}$ & $\mathbf{2 0 1 5}$ & $\mathbf{2 0 1 6}$ & $\mathbf{2 0 1 7}$ & $\mathbf{2 0 1 8}$ \\
\hline LDR (\%) & 84,95 & 85,91 & 84,61 & 84,97 & 87,22 \\
\hline NPL (\%) & 1,20 & 1,23 & 1,17 & 1,18 & 1,15 \\
\hline CAR(\%) & 17,01 & 17,96 & 19,70 & 19,73 & 19,83 \\
\hline GCG(score) & 83,95 & 83,90 & 85,03 & 85,78 & 88,27 \\
\hline ROA(\%) & 2,50 & 2,40 & 2,42 & 2,53 & 2,70 \\
\hline
\end{tabular}

Sources: Financial statement in IDX; data processed.

Based on table 1, it can be seen that the financial ratios of banks registered at banking companies registered at the Indonesia Institute for Corporate Governance (IICG) in the 2014-2018 period fluctuated each year. Increases and decreases in ROA are also followed by three independent variables: loan to deposit ratio, non-performing loans, capital adequacy ratio and good corporate governance as an intervening variable. 


\section{I.2. Research Objectives}

1. Want to test how the influence Loan to Deposit Ratio, Non-Performing Loans, Capital Adequacy Ratio on Good Corporate Governance

2. Want to test how the influence of Loan to Deposit Ratio, Net Performing Loans, Capital Adequacy Ratio on Return On Assets.

\section{LITERATURE REVIEW AND HYPOTHESIS FORMULATION}

\section{Grand Theory, Empirical Evidence and Hypothesis Formulation}

\section{Agency Theory}

According to Atmaja (2018), Agency theory states that there is an asymmetry between managers (agents) and shareholders (principals) where managers are more aware of internal information and company prospects in the future compared to shareholders and other stakeholders. Principals will sacrifice their resources in the form of compensation received by the agent, with compensation given to the agent, the principal hopes to reduce differences of opinion and reduce actions that deviate from the interests of the principal. For this reason, principal will set rules such as GCG to oversee managers or banker.

\section{Trade-Off Theory}

According to Brigham, and Ehrhardt (2005). This theory explains the idea that how much is the company's debt and how much is the company's equity resulting in a balance between costs and profits. This theory states that a company has an optimal debt level and tries to adjust its actual debt level to the optimal point when the company is at a debt level that is too high (overleveraged) or too low (undelivered). In a stable condition, the company will adjust its debt level to the average level of the debt in the long run. Debt and equity balances are needed so that managers (agents) can achieve optimal company or bank ROA.

\section{Signaling Theory}

According to Brigham and Hosuton (2014), signaling theory is a behavior of company management in giving instructions to investors regarding management's views on the company's prospects for the future. In the framework of signal theory, it is stated that the impetus of the company to provide information is because there is information asymmetry between company managers and outsiders, this is because company managers know more information about the company and prospects to come than outsiders. By submitting this information to an external party, the external party is expected to provide a proportional and positive response. So the profit or ROA is optimal.

\section{Relationship of Loan to Deposit Ratio to Good Corporate Governance.}

According to Mulyono (1995), the LDR ratio is the ratio of the ratio between the number of funds channeled to the community (credit) with the number of community funds and own capital used. This ratio illustrates the ability of banks to repay withdrawals by depositors by relying on loans provided as a source of liquidity. The higher this ratio the lower the ability of bank liquidity (Dendawijaya, 2000).

The following are the results of previous studies: Kiswanto \& Ari (2016) states that the Loan to deposit ratio has a significant effect on Good Corporate Governance.

Based on previous research above, it can be made a hypothesis of the relationship between the two variables as follows:

H1: LDR has a positive effect on GCG

\section{Relationship of Non-Performing Loan to Good Corporate Governance.}

According to Ismail (2009), Non-Performing Loan (NPL) is a situation where the customer is unable to pay part or all of his obligations to the bank as agreed. Each bank must be able to manage credit well in giving credit to the public and in returning credit according to the terms and conditions that apply so as not to cause problem loans. 
According to Taswan (2006) and Kisman (2017), the ratio used to assess financial performance in managing nonperforming loans is the NPL (Non-Performing Loan) ratio. Nonperforming loans are classified as Collectible, Current, Substandard, Doubtful and Loss. The smaller the NPL, the smaller the credit risk borne by the bank. Banks in conducting credit must conduct an analysis of the ability of debtors to repay their obligations. After credit is granted, banks are required to monitor the use of credit and the ability and compliance of debtors in fulfilling their obligations. The Bank conducts a review and binding of collateral to minimize credit risk. Banking practitioners agree that the safe limit of a bank's NPL must not exceed 5\%.

Research by Ika Permata and Retno (2018), states that Net Performing Loans have a significant and positive effect on Good Corporate Governance.

Based on previous research above, it can be made a hypothesis of the relationship between the two variables as follows:

H2: NPL has a positive effect on GCG.

\section{Relationship of Capital Adequacy Ratio to Good Corporate Governance}

According to Kuncoro (2011), CAR is capital adequacy ratio that shows banks in maintaining sufficient capital and the ability of bank management to identify, measure, monitor, and control risks that arise that can affect the amount of bank capital.

According to Bank Central of Indonesia (Number 9/13 / PBI / 2007), CAR is the provision of minimum capital for banks based on broad risk assets, both assets listed in the balance sheet and administrative assets as reflected in obligations that are still contingent and / or commitments provided by banks for third parties or market risk. In other words, CAR is the ratio of bank performance to measure the adequacy of capital owned by banks to support assets that contain or generate risk, for example, loans.

Research by Kiswanto \& Ari (2016), states that the Capital Adequacy Ratio has a significant effect on Good Corporate Governance.

Based on previous research above, it can be made a hypothesis of the relationship between the two variables as follows:

H3: CAR has a positive effect on GCG.

Relationship of Loan to Deposit Ratio, Non-Performing Loans, Capital Adequacy Ratio simultaneously to Good Corporate Governance

Based on the existing theories and previous research, the researcher wants to analyze the effect of Loan to Deposit Ratio, Net Performing Loans, Capital Adequacy simultaneously on Good Corporate Governance. How the relationship between variables above can be seen from the explanation below.

Banking liquidity (LDR) needs to be managed to meet the needs when customers take their funds and distribute loans (credit) to borrowers (debtors). If the LDR value is too high, it means that the bank does not have sufficient liquidity to cover its obligations to customers (depositor, third-party funds or in Indonesia called the DPK). Conversely, if the LDR value is too low, it means that banks have sufficient liquidity but their income (interest income ) may be lower because as is well known, the banking world earns income through loans.

The higher Net Performing Loans can mean that the quality of bank credit is getting worse and the NPL ratio is not reasonable causing loss of opportunity to obtain income from loans and banks must accept losses and operational activities due to non-performing loans.

Capital Adequacy Ratio is the ratio of bank performance to measure the adequacy of capital owned by banks to support assets that contain or generate risk, for example, loans granted. 
Based on relationship and previous research above, it can be made a hypothesis of the relationship between the four variables as follows:

H4: Loan to Deposit Ratio, Net Performing Loans and Capital Adequacy Ratio have simultaneously effect on Good Corporate Governance

\section{Relationship of Loan to Deposit Ratio to Return On Assets.}

Loan to Deposit Ratio (LDR) reflects the ratio between financing provided by commercial banks to their customers compared with funds that have been entered or collected from the public. Banks that have large total assets, have the opportunity to extend credit to the borrowers in large numbers, so as to obtain high profits (Alper et al., 2011). The size of the LDR ratio of a bank will affect bank profitability. The higher the LDR owned by a bank also shows that the bank's ability to obtain profits the better. So it can be said that LDR has a positive effect on ROA (Kisman,2017).

Research by Restiyana (2011) shows that LDR has a positive effect on ROA.

Based on previous research above, it can be made a hypothesis of the relationship between the two variables as follows:

H5: Loan to Deposit Ratio has a positive effect on Return On Assets.

\section{Relationship of Non-Performing Loans to Return On Assets.}

The NPL ratio shows the ability of bank management to managing non-performing loans provided by banks. The higher the NPL ratio, the worse the quality of bank credit that causes the number of problem loans is greater so that it can cause the possibility of a bank in a greater problematic condition.

The following are the results of several previous studies that Non-Performing Loans negatively affect ROA (Indah and Arief,2015). Meanwhile, according to Ayu (Aye et al.,2017) and Kisman (2017), that the Non-Performing Loan has a significant effect on profitability.

Based on explanation above, it can be made a hypothesis of the relationship between the two variables as follows: H6: Non-Performing has negative effects on Return On Assets.

\section{Relationship of Capital Adequacy Ratio to Return On Assets}

According to Darmawi (2011), one component of the capital factor is capital adequacy. The ratio to test the bank's capital adequacy ratio is CAR (Capital Adequacy Ratio). CAR shows how far all bank assets that contain ratios that show how far all bank assets that contain risks (credit, inclusion of securities, bills at other banks) are financed from the bank's own capital funds in addition to obtaining funds from sources outside the bank, such as public funds, loans (debt), and others.

Research by Restiyana (2011) and Deden (2016), shows that the Capital Adequacy Ratio has a positive and significant effect on Return On Assets.

Based on previous research above, it can be made a hypothesis of the relationship between the two variables as follows:

H7: Capital Adequacy Ratio has a positive effect on Return On Assets.

\section{Relationship of Good Corporate Governance to Return on Assets.}

Research on good corporate governance provides empirical evidence that the variable of good corporate governance is an important factor in determining company value and influencing company profitability.

Good corporate governance also guarantees profit and security of funds invested in banks that will not be embezzled by bank managers. The implementation of good corporate governance can prevent mistakes in decision making so that it will automatically increase the value of the company, which is reflected in profitability. 
Research by Anjani and Yadnya (2017) Good Corporate Governance has a significant effect on Return On Assets.

Based on previous research and explanation above, it can be made a hypothesis of the relationship between the two variables as follows:

H8: Good Corporate Government has a positive effect on Return On Assets.

\section{Relationship of Loan to Deposit Ratio, Net Performing Loans, Capital Adequacy Ratio and Good Corporate Governance simultaneously to Return On Assets}

Based on the existing theories and previous research, this study wants to analyze the effect of Loan to Deposit Ratio, Non-Performing Loans, Capital Adequacy Ratio and Good Corporate Governance simultaneously on Return on Assets. How the relationship between variables above can be seen from the explanation below.

Loan to Deposit Ratio, Non-Performing Loans, Capital Adequacy Ratio and Good Corporate Governance are of the ratio that can be used in terms of measuring the financial performance of the bank. Then the changes in the four ratios also partially affect ROA as explained above. In line with the partial influence above, it is simultaneously expected that LDR, NPL, CAR and GCG influence ROA.

Based on explanation above, it can be made a hypothesis of the relationship between the five variables as follows: H9: Loan to Deposit Ratio, Non-Performing Loans, Capital Adequacy Ratio and Good Corporate Governance have simultaneously effect on Return On Assets.

\section{Relationship of Loan to Deposit Ratio, Net Performing Loans, Capital Adequacy Ratio to Return On Assets with Good Corporate Governance as an intervening variable.}

Loan to Deposit Ratio is a ratio that measures the extent of the bank's ability to repay withdrawals of funds made by depositors by relying on loans provided as a source of liquidity. The higher this ratio, the lower the liquidity of the bank concerned. But on the contrary, the lower the LDR ratio, the higher the liquidity of the bank concerned. This ratio is also an indicator of the vulnerability and ability of a bank.

A non-performing loan is a situation where the customer is unable to pay part or all of his obligations to the bank as agreed. Each bank must be able to manage credit well in giving credit to the public and in returning credit according to the terms and conditions that apply so as not to cause problem loans. The smaller the NPL, the smaller the credit risk borne by the bank.

Capital Adequacy Ratio is capital adequacy that shows banks in maintaining adequate capital and the ability of bank management to identify, measure, supervise, and control the risks that arise that can affect the amount of bank capital (Kuncoro, 2011).

Good Corporate Governance (GCG) is a healthy corporate governance procedure that has been introduced by the Indonesian government and the International Monetary Fund (IMF). This concept is expected to protect shareholders and creditors so that they can regain their investment.

Return On Assets is a ratio used to measure a company's ability to generate profits by using the total assets owned by the company after adjusting for costs to fund these assets (Hanafi and Halim, 2007).

Based on the description above, it can be seen that the independent variables with intervening variables in research affect each other and have a relationship with the dependent variable. The relationship that occurs between the independent variable and the intervening variable is expected to be an interrupting variable between the independent variable and the dependent variable so that the independent variable does not directly affect the emergence of the dependent variable.

Based on previous research and explanation above, it can be made a hypothesis of the relationship between the five variables as follows: 
H10: Loan to Deposit Ratio, Non-Performing Loans, Capital Adequacy Ratio have an effect on Return On Assets with Good Corporate Governance as an intervening variable.

\section{III.RESEARCH METHODS}

\section{III.1 RESEARCH METHODS}

The object of this study is the Banking Companies listed on the Indonesia Stock Exchange, which have a score of Corporate Governance Perception Index of the Indonesian Institute for Corporate Governance Period 2014 - 2018. Types of data used in this study are secondary data, namely in the form of panel data for all related variables. The population in this study is banking with a total of 45 companies.

Based on sample selection, the total sample of Banking listed on the Indonesia Stock Exchange that has a score of Corporate Governance Perception Index of The Indonesian Institute for Corporate Governance (IICG) that meets the criteria is 10 companies listed on the Indonesia Stock Exchange in 2014-2018.

\section{III.2. POPULATION AND SAMPLE}

The population used in this study is that the banks listed on the Indonesia Stock Exchange have a score of 10 companies in the Corporate Governance Perception Index of the Indonesian Institute for Corporate Governance (IICG).

The sampling criteria for this study are as follows:

1. Banking Companies listed on the Indonesia Stock Exchange during the observation period, namely 2014 - 2018.

2. Companies that publish data on company financial statements that are published on the Indonesia Stock Exchange at the end of each year during monitoring, namely 2014 - 2018.

3. Banking Companies that have a Corporate Governance Perception Index of the 2014 Indonesian Corporate Governance Institute (IICG).

This study uses secondary data. Secondary data is data that has been processed by the relevant institution which is sourced from the financial statements of the related company that has been audited and published to the general public. The financial report data is obtained from the website of the Indonesia Stock Exchange through www.idx.co.id.

\section{III.3 METHOD OF ANALYSIS}

In this study, the analysis method is carried out by path analysis which is a development of the regression model. Through this path analysis, the regression equation involves independent and dependent variables by testing intervening variables. Path analysis can also measure the relationship between variables in the model both directly and indirectly.

\section{III.4. DEFINITION ON OF OPERATIONAL VARIABLES}

\section{Dependent Variables}

The definition of operational variables is very important in research. This is intended to avoid misunderstandings or differences in perceptions regarding the data to be collected. In this study Return On Assets are used as dependent variables.

Return On Assets is a ratio used to measure a company's ability to generate profits.

\section{Independent Variables}

Loan to Deposit Ratio (LDR)

Loan to Deposit Ratio (LDR) is the ratio between the total volume of credit extended by banks and the number of funds received from various sources. LDR is the company's financial ratio related to liquidity. 


\section{Non-Performing Loans (NPL)}

Part of bank credit that is not smooth until the bad debt where the bank did not manage to pull it back

\section{Capital Adequacy Ratio (CAR)}

Capital Adequacy Ratio is the ratio of the adequacy of capital owned by banks to support assets that contain or generate risk, for example, loans granted.

\section{Intervening Variable}

GCG is a score of Corporate Governance Perception Index of The Indonesian Institute for Corporate Governance (IICG).

\section{III.5. DATA ANALYSIS}

The analysis technique used in this study is path analysis. Before the path analysis is carried out, the assumption of path analysis must first test. The test consists of normality, multicollinearity, and heteroscedasticity. The path analysis model is as follows:

\section{Substructure Equation 1:}

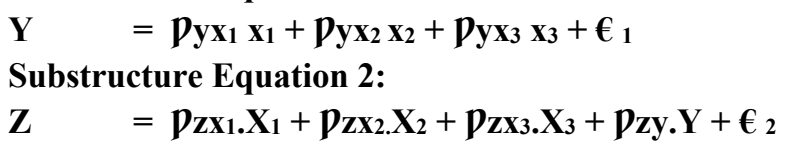

Figure 1: Framework for Research Models

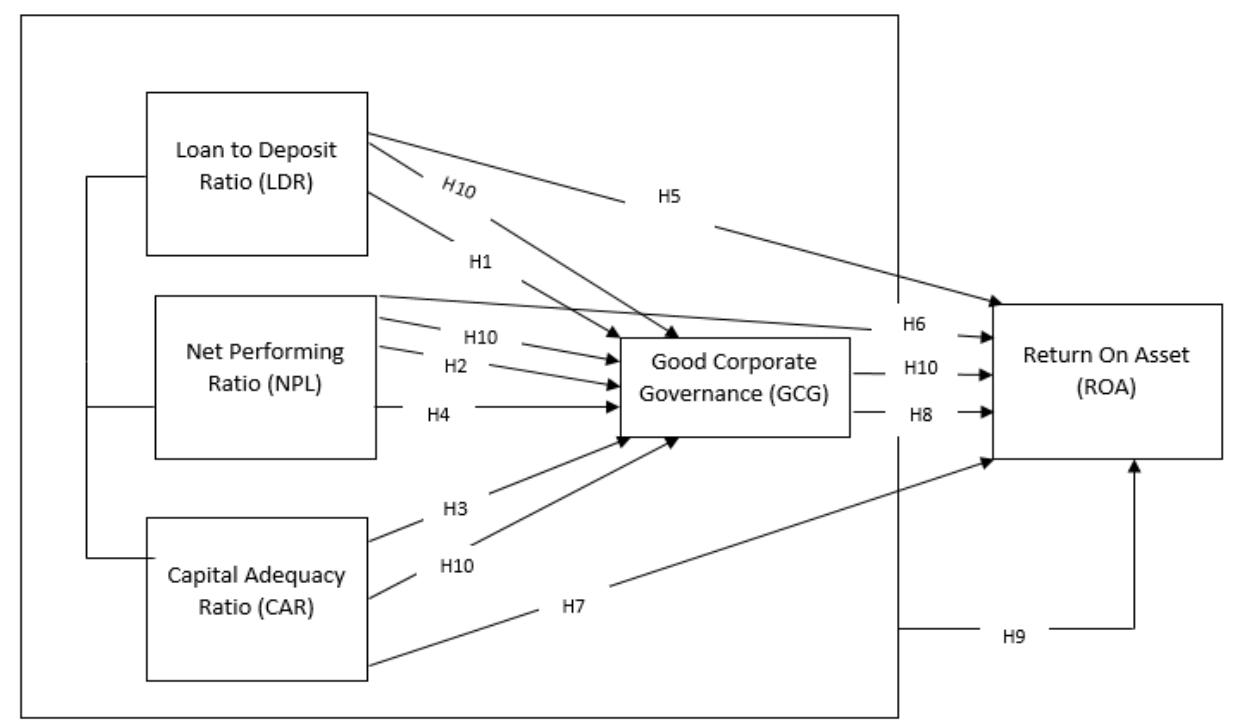

The application of GCG principles and practices will increase domestic investor confidence in the company. The benefits of implementing Good Corporate Governance (Daniri, 2014) can reduce agency costs and the cost of capital, and increase profitability (ROA) also the value of shares. The challenges of banking in the future not only lie in intense competition but also include weak banking capabilities, sustainable profitability and efficiency of bank operations, customer protection and information technology that still needs to be improved.

Trust and partiality in the interests of the community are a final estuary of banking integrity. Banking consolidation is based on three strengths, namely, capital-based, good corporate governance and corporate culture will be the eyes of the banking heart and are expected to illuminate national integrity. The application of GCG principles and practices will increase domestic and international investor confidence in the company and ultimately can increase profiability and value of shares. 


\section{RESULTS AND DISCUSSION}

Before conducting statistical analysis, the data to be processed, first must meet the regression analysis assumptions (Ghozali,2013).

\section{TESTING OF THE REGRESSION ANALYSIS ASSUMPTION AND RESULT.}

\section{Substructure Equation 1:}

Before conducting statistical analysis, the data to be processed, first must meet the regression analysis assumptions.

Table 2: One-Sample Kolmogorov-Smirnov Test ( Normality Test)

\begin{tabular}{lll} 
& & $\begin{array}{l}\text { Unstandardized } \\
\text { Residual }\end{array}$ \\
\hline $\mathrm{N}$ & & 50 \\
\hline Normal Parameters & & \\
& Mean &, 0000000 \\
\cline { 2 - 3 } Most Extreme Differences & Std. Deviation &, 01240605 \\
\cline { 2 - 3 } & Absolute &, 091 \\
\cline { 2 - 3 } & Positive &, 050 \\
\cline { 2 - 3 } & Negative &,- 091 \\
\hline Test Statistic &, 091 \\
\hline Asymp. Sig. (2-tailed) &, $200^{\text {c,d }}$ \\
\hline $\begin{array}{l}\text { a. Test distribution is Normal. } \\
\text { b. Calculated from data. } \\
\text { c. Lilliefors Significance Correction. }\end{array}$ \\
\hline
\end{tabular}

In table 2 above, the Asymp value is obtained. Sig (2- tailed) of 0.200 or can be written as a probability value (Pvalue $)=0.200>0.05$ or Ho is accepted. Thus, residual data are normally distributed.

Table 3: Autocorrelation Test (Durbin- Watson) Model Summary

\begin{tabular}{|c|c|c|c|c|c|}
\hline Model & $\mathrm{R}$ & R Square & $\begin{array}{l}\text { Adjusted } \quad \mathrm{R} \\
\text { Square }\end{array}$ & $\begin{array}{l}\text { Std. Error of the } \\
\text { Estimate }\end{array}$ & Durbin-Watson \\
\hline 1 &, $696^{\mathrm{a}}$ &, 485 & ,451 &, 01280 & ,872 \\
\hline
\end{tabular}

From Table 3 above, the results of autocorrelation with Durbin - Watson are 0.872, which means that the autocorrelation category does not occur because the D-W number is between -2 to 2 (Singgih, 2013 )

Table 4 : Tolerance dan VIF (Multicollinearity Test)

\begin{tabular}{|l|l|l|}
\hline \multirow{2}{*}{ Model } & \multicolumn{2}{|l|}{ Colinearity Statistics } \\
\cline { 2 - 3 } & Tolerance & VIF \\
\hline $1 \quad$ (Constant) & & \\
\hline LDR & 0,888 & 1,126 \\
\hline NPL & 0,825 & 1,212 \\
\hline CAR & 0,827 & 1,208 \\
\hline
\end{tabular}

Source: data processed

Based on the results of testing the tolerance value (see Table 4 above) also shows that there is no independent variable that has a tolerance value below or less than 0.10 , which means that there is no correlation between the 
independent variables whose value is more than $95 \%$. The results of the calculation of Variance Inflation Factor (VIF) also showed the same results, namely, there are no independent variables that have a VIF value $\geq 10$. So it can be said and concluded that there is no multicollinearity between the independent variables in the regression model.

Figure 2: Scatterplot graph (Heteroscedastisity Test)

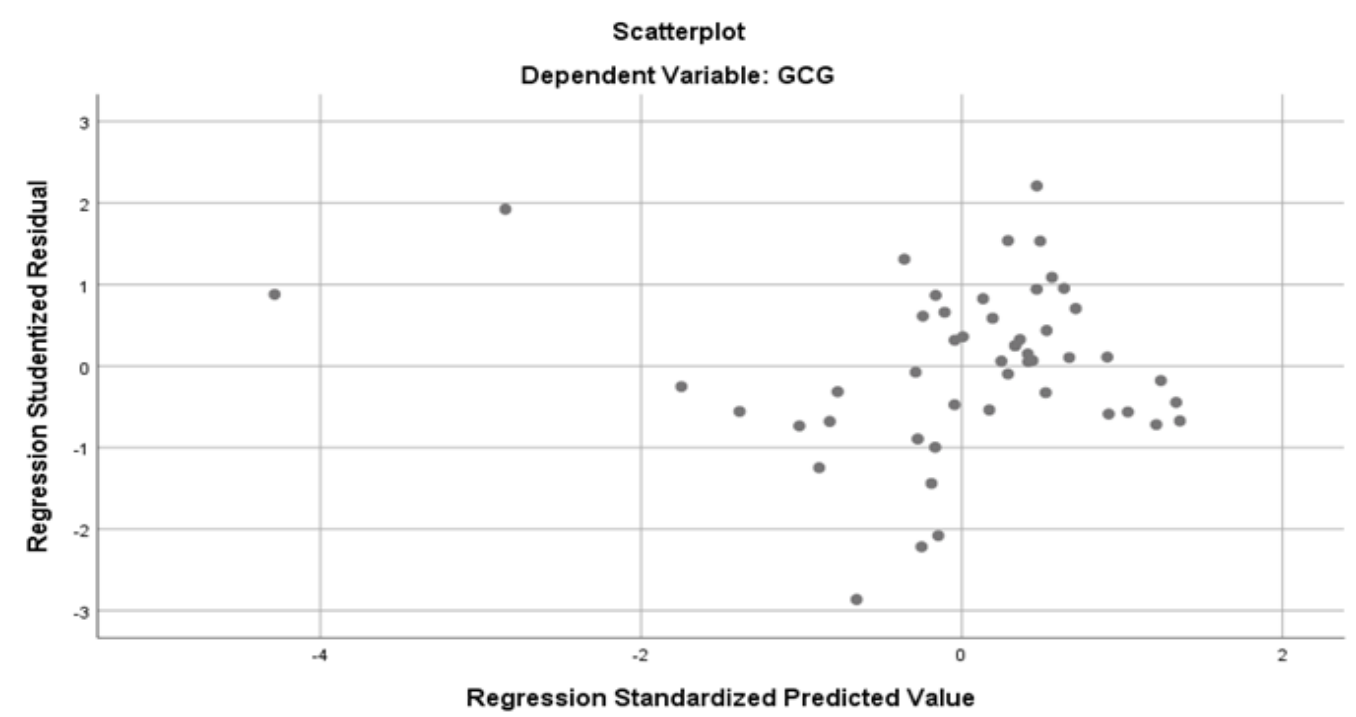

Based on Figure 2 above, there is a scatterplot graph that shows the points of diffuse and does not form certain clear patterns. So it can be concluded that there are no symptoms of heteroscedasticity.

Table 5: Summary of Results : Substructure Equation 1

\begin{tabular}{|c|c|c|c|c|c|}
\hline Model & $\begin{array}{l}\text { Standardized } \\
\text { Coefficients B }\end{array}$ & $\begin{array}{l}\text { t-test } \\
\text { Sig. }\end{array}$ & Description & F-test and Sig. & R-Square \\
\hline $\mathrm{LDR} \longrightarrow \mathrm{GCG}$ &,- 244 & 0,035 & Significant & \multirow{3}{*}{$\begin{array}{l}0.000 \\
\text { Significant }\end{array}$} & \multirow{3}{*}{0.485} \\
\hline $\mathrm{NPL} \longrightarrow \mathrm{GCG}$ &,- 560 & 0,000 & Significant & & \\
\hline $\mathrm{CAR} \longrightarrow \mathrm{GCG}$ & ,239 & 0,046 & Significant & & \\
\hline
\end{tabular}

Table 5 above is a summary table for substructural model equations 1 . The data information contained in table 5 is derived from the processing of multiple regression analysis data. Table 5 will be used to assess whether the substructural 1 equation model is good enough (fit model) or not. Then the results in table 5 will be used to see the direct or non-direct effect on ROA in Figure 4.

Based on the table, the substructural 1 equation model is considered to be quite good (fit model) because all the independent variables (LDR, NPL and CAR) are significant and simultaneously also significant (see F-test). The R-squares are quite moderate. So overall the substructural 1 equation model and its coefficient information are valid and unbiased. Therefore we can draw conclusions using the data in table 5. Futhermore, the results can be used for the path analysis that is the basis of this research analysis (see Figure 4). 


\section{Substructure Equation 2:}

Table 6: One-Sample Kolmogorov-Smirnov Test (Normality Test)

\begin{tabular}{|c|c|c|}
\hline & & $\begin{array}{l}\text { Unstandardized } \\
\text { Residual }\end{array}$ \\
\hline \multicolumn{2}{|l|}{$\mathrm{N}$} & 50 \\
\hline \multirow[t]{2}{*}{ Normal Parameters ${ }^{\mathrm{a}, \mathrm{b}}$} & Mean & ,0000000 \\
\hline & Std. Deviation & ,34215523 \\
\hline \multirow[t]{3}{*}{ Most Extreme Differences } & Absolute & ,091 \\
\hline & Positive & ,091 \\
\hline & Negative &,- 071 \\
\hline \multicolumn{2}{|l|}{ Test Statistic } & ,091 \\
\hline \multicolumn{2}{|l|}{ Asymp. Sig. (2-tailed) } & $200^{\mathrm{c}, \mathrm{d}}$ \\
\hline $\begin{array}{l}\text { a. Test distribution is Norm } \\
\text { b. Calculated from data. } \\
\text { c. Lilliefors Significance C } \\
\text { d. This is a lower bound of }\end{array}$ & $\begin{array}{l}\text { ection. } \\
\text { true significan }\end{array}$ & \\
\hline
\end{tabular}

Tabel 7: Autocorrelation Test ( Durbin- Watson) Model Summary ${ }^{\mathrm{b}}$

\begin{tabular}{|c|c|c|c|c|c|}
\hline Model & $\mathrm{R}$ & R Square & $\begin{array}{l}\text { Adjusted } \quad \mathrm{R} \\
\text { Square }\end{array}$ & $\begin{array}{l}\text { Std. Error of the } \\
\text { Estimate }\end{array}$ & Durbin-Watson \\
\hline 1 &, $892^{\mathrm{a}}$ & ,795 & ,777 & ,35704 & 1,328 \\
\hline
\end{tabular}

From Table 7 above, it can be seen that the Durbin-Watson value is 1.328 in the autocorrelation free region because it is between -2 to +2 . So the decision taken in the autocorrelation test is accepted Ho, reject H1. It means that this test does not contain an autocorrelation problem. Thus it can be concluded that the regression equation model is free from autocorrelation symptons.

Tabel 8: Tolerance dan VIF (Multicollinearity Test)

\begin{tabular}{|l|l|l|}
\hline \multirow{2}{*}{ Model } & \multicolumn{2}{|l|}{ Colinearity Statistics } \\
\cline { 2 - 3 } & Tolerance & VIF \\
\hline $1 \quad$ (Constant) & & \\
\hline LDR & 0,805 & 1,241 \\
\hline NPL & 0,549 & 1,821 \\
\hline CAR & 0,758 & 1,319 \\
\hline GCG & 0,515 & 1,941 \\
\hline
\end{tabular}

Source: data processed

Based on Table 8, the results of testing the tolerance value also shows that there is no independent variable that has a tolerance value below or less than 0.10 , which means that there is no correlation between the independent 
variables whose value is more than $95 \%$. The results of the calculation of Variance Inflation Factor (VIF) also showed the same results, namely, there are no independent variables that have a VIF value $\geq 10$.

Figure 3. Scatterplot graph (Heteroscedastisity Test)

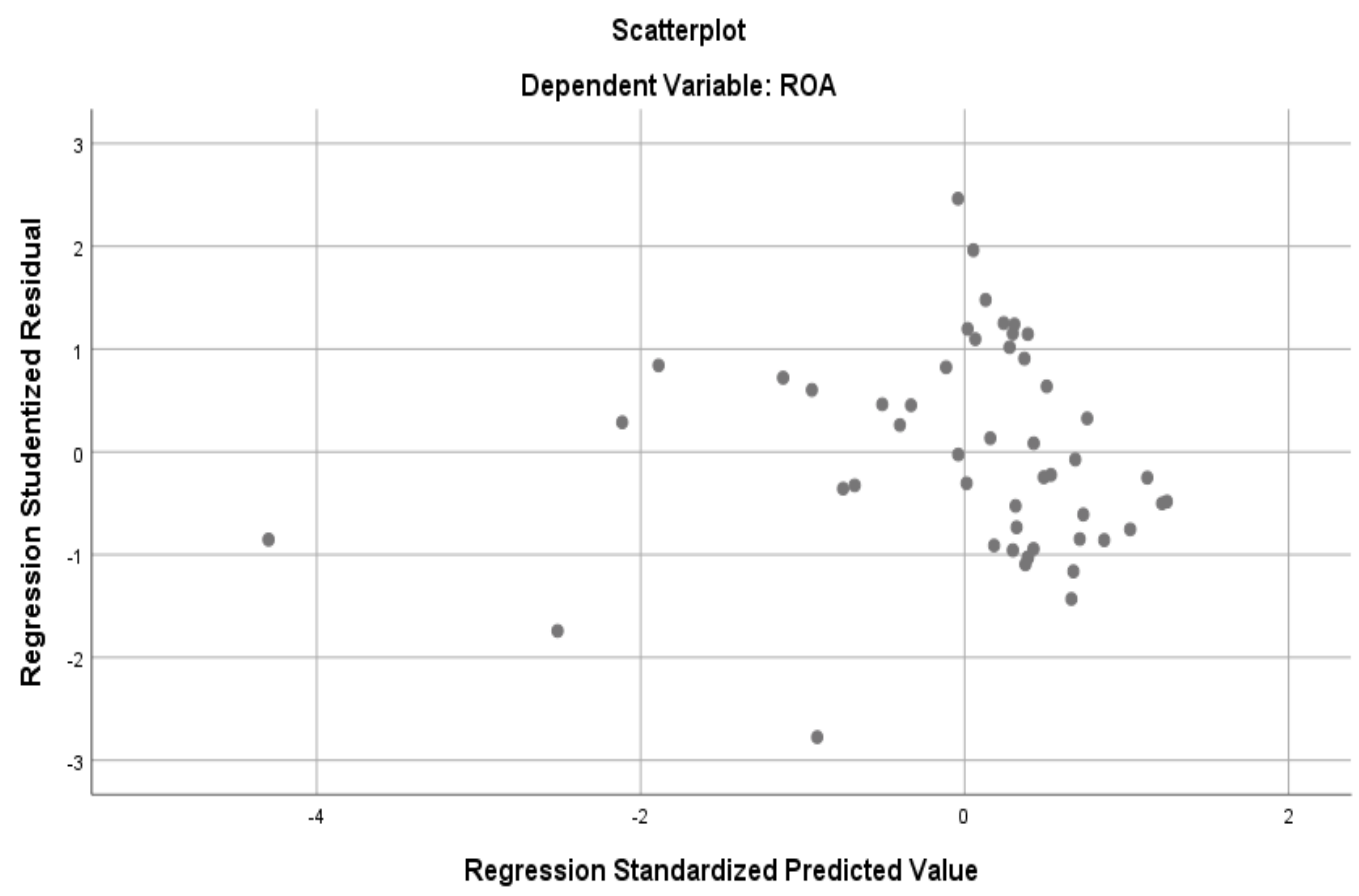

Based on Figure 3 above, there is a Scatterplot graph that shows the scattered points do not form a certain clear pattern. So it can be concluded that there are no symptoms of heteroscedasticity.

Table 9: Summary of Results: Substructure Equation 2

\begin{tabular}{|l|c|l|l|l|l|}
\hline Model & $\begin{array}{l}\text { Standardized } \\
\text { Coefficients B }\end{array}$ & $\begin{array}{l}\text { t-test } \\
\text { Sig. }\end{array}$ & Description & $\begin{array}{l}\text { F-test and } \\
\text { Sig. }\end{array}$ & R-Square \\
\cline { 1 - 4 } LDR $\longrightarrow$ ROA & -.062 & 0.411 & Not Significant & \multirow{2}{*}{0.000} & \multirow{2}{*}{0.795} \\
\cline { 1 - 4 } SPL $\longrightarrow$ Significant & \\
\cline { 1 - 3 } CAR $\longrightarrow$ GCG $\longrightarrow$ ROA & -.505 & 0.000 & Significant & \\
\hline
\end{tabular}

Table 9 above is a summary table for substructural model equations 2 . The data information contained in table 9 is derived from the processing of multiple regression analysis data. Table 9 will be used to assess whether the substructural 2 equation model is good enough (fit model) or not. Then the results in table 9 will be used to see the direct or non-direct effect on ROA in Figure 4.

Based on the table, the substructural 2 equation model is considered to be quite fit because all the independent variables (NPL, CAR and GCG) except LDR are significant. LDR not significant because the size of the interbank credit that is sampled is very different. Simultaneously, all variables also significant (see F-test). The R-squares are high. So overall the substructural 2 equation model and its coefficient information are valid and unbiased. Therefore we can draw conclusions using the data in table 9. Futhermore, the results can be used for the path analysis that is the basis of this research analysis (see Figure 4). 


\section{Path Analysis}

Path Analysis is to combine the data in Table 5 and Table 9 to see the direct and indirect effects in order to solve the problem of how to improve ROA by using GCG intervening variables.

Figure 4: Cooficient of Path Analysis

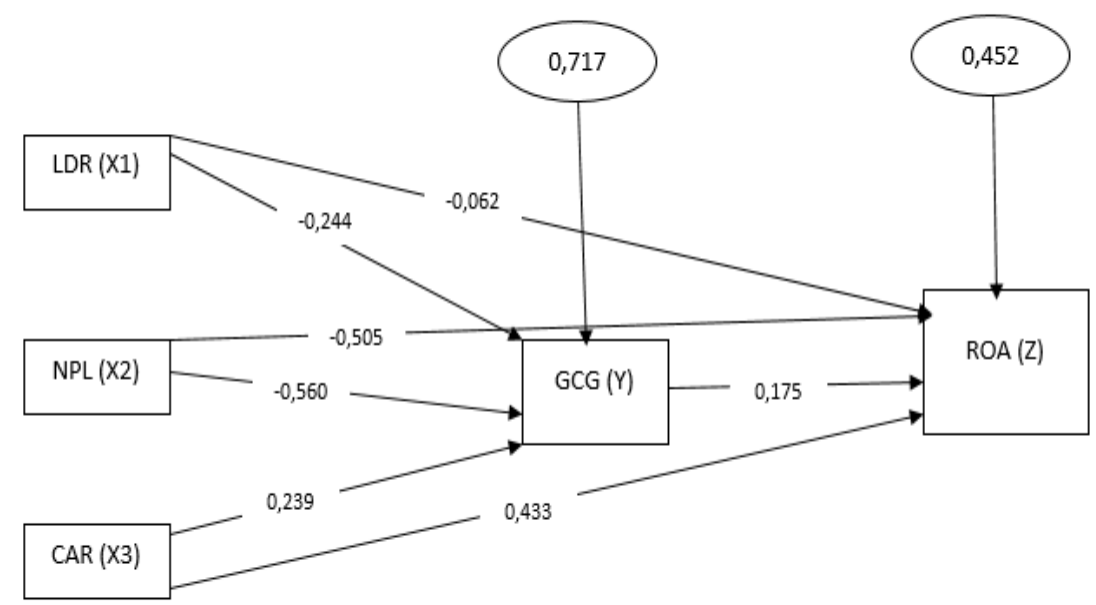

Source: data processed

The path coefficient interpretation is as follows:

- Effect of LDR on ROA :

Direct influence $=-0,062$

Indirect influence (through GCG) $=-0,244 \times 0,175=-0,0427$

Total influence $=-0,062+(-0,0427)=-0,1047$

- Effect of NPL on ROA

Direct influence $=-0,505$

Indirect influence (through GCG) $=-0,560 \times 0,175=0,098$

Total influence $=-0,505+0,098=-0,407$

- $\quad$ Effect of CAR on ROA

Direct influence $=0,433$

Indirect influence (through GCG) $=0,239 \times 0,175=0,0418$

Total influence $=0,433+0,0418=0,4748$

- The effect of GCG on ROA $=0,175$

The above results are summarized in Table 10. Table 10 will be able to show the role of each variable influencing the ROA and the role of GCG as intervening variable.

Tabel 10: Summary of the Value of Direct Effects, Indirect Effects and Total Effects Between Variables

\begin{tabular}{|l|l|l|l|}
\hline Influence of Variables & $\begin{array}{l}\text { Direct } \\
\text { influence }\end{array}$ & $\begin{array}{l}\text { Indirect influence } \\
\text { (through GCG) }: \\
\text { intervening } \\
\text { variable }\end{array}$ & Total influence \\
\hline LDR (X1) $\longrightarrow$ ROA (Z) & -0.062 & $-0.244 \times 0.175=-$ & -0.1047 \\
0.0427 & \\
\hline
\end{tabular}




\begin{tabular}{|l|l|l|l|}
\hline NPL (X2) $\longrightarrow$ ROA (Z) & -0.505 & $\begin{array}{l}-0.560 \text { x } \\
0.175=\end{array}$ & -0.407 \\
\hline CAR (X3) $\longrightarrow$ ROA (Z) & 0.433 & 0.239 x $0.175=$ & 0.4748 \\
& & 0.0418 & \\
\hline GCG (Y) $\longrightarrow$ ROA (Z) & 0.175 & & 0.175 \\
\hline LDR (X1) $\longrightarrow$ GCG (Y) & -0.244 & & -0.244 \\
\hline NPL (X1) $\longrightarrow$ GCG (Y) & -0.560 & & -0.560 \\
\hline CAR(X1) $\longrightarrow$ GCG (Y) & 0.239 & & 0.239 \\
\hline
\end{tabular}

Source: Data Process

Based on the above calculation Table 10, it can be concluded as follows:

1. Loan to Deposit Ratio has an indirect effect on Return On Assets, from the calculation results that the direct effect of -0.062 is smaller than the indirect effect - 0.0427 (through GCG). Because LDR to ROA directly has no significant effect based on table 9. So it is better to influence LDR on ROA through GCG (intervening variable) than directly. This means that LDR in influencing ROA through GCG can be seen GCG as intervening variable and here plays a role in increasing ROA. This role is due to GCG improving loan management (LDR) and reducing the risk of bad credit (NPL) and capital management (CAR). So that the overall total LDR effect on ROA increases when managing GCG better.

2. Non-Performing Loans have an indirect effect on Return On Assets, from the results of calculations that the direct effect of -0.505 (lowers ROA).But indirect effect of 0.098 (through GCG). This path also shows that GCG acts as an intervening variable from NPL to ROA. Like the LDR to ROA path. NPL has an effect on increasing ROA through the application of GCG because the decrease in NPL in this period has an impact on improving GCG scores. An increased GCG score means better bank governance. Furthermore, it affects the increase in ROA. So once again here the role of GCG as an intervening variable between NPL and ROA is clearly seen because it increases ROA. The role of GCG has also been shown in the upper path between the influence of LDR on ROA through GCG. GCG here shows its role of reducing smaller ROA decreases due to an increase in NPL when there is GCG as an intervening variable.

3. Capital Adequacy Ratio has a direct effect on Return On Assets, from the calculation results that the direct effect of 0.433 , and this increase in ROA will increase if the bank applies GCG. The addition of ROA due to CAR (through GCG) is 0.0418 . So that overall ROA increases higher than not applying GCG. Capital Adequacy Ratio is the ratio of bank performance to measure the adequacy of capital owned by banks to support assets that contain or generate risk. The increasing quality of CAR will be an influence on the increase in profits shown by ROA, this is very supportive for the continuity of business activities more adequately on capital, the tendency of an increase in profits generated on assets will also increase. So that this condition needs to be maintained by the Bank, or more enhanced its CAR because more CAR increases automatically raise the public's trust in the Bank that optimal management of CAR can increase the value of GCG.

4. The role of GCG can improve ROA. And that role can be seen by comparing the direct influence of each variable and indirectly through intervening. By intervening in good corporate governance, the effect of using GCG is higher than not using GCG. This shows that GCG has a role in increasing ROA due to changes in LDR, NPL and CAR variables. This means that if a bank wants to increase profits, not only loans, bad loans and capital should be considered, but the Good Corporate Government must also be maintained.

\section{CONCLUSION}

Based on the results of statistical tests obtained after data collection, data processing, hypothesis testing, and analysis and discussion related to the research hypothesis, the researcher draws the conclusions as follows:

1. Simultaneously the variable loan to deposit, non-performing loans, capital adequacy ratio have significant effect to good corporate governance.

2. Through intervening good corporate governance variables, simultaneously the non-performing loans, capital adequacy ratio, good corporate governance have a significant effect on return on assets. Partially, 
non-performing loans, capital adequacy ratios, good corporate governance have an influence on asset returns, But the loan to deposit does not have a significant effect.

\section{RECOMMENDATION}

Based on the results of research and discussion, there are several suggestions that can be given, including:

1. For the management of banking companies to be prudent in managing funds and liquidity in accordance with the principles of good corporate governance. Companies that manage policies in managing liquidity in accordance with applicable banking regulations and principles of good corporate governance (ALMA).

2. For the public, investors or potential investors, to be more careful in analyzing the factors that influence return on assets. In seeing the effect of variables on return on assets, it is better to include good corporate governance (GCG) as an intervening variable. Considering that GCG will increasingly look at the effect of each variable on ROA. Thus increasing the decision taken. This research has provided evidence.

3. For future researchers, it is better to add an analysis of the influence of other variables not used in this study for better results.

\section{References}

Ari,Anjani Luh Putu ., Yadnya,I Putu . 2017. Pengaruh Good Corporate Governance terhadap profitabilitas pada perusahaan perbankan yang terdaftar di BEI. E-Jurnal Manajemen Universitas Udayana. Volume 5 Tahun 2017.

Auliya, Rizka. 2014. Pengaruh risk, Good Corporate governance, earning dan capital terhadap profitabilitas pada bank umum swasta nasional devisa di indonesia. STIE Perbanas Surabaya.

Bernardin Deden Edwar Yokeu. 2016. Pengaruh Capital Adequacy Ratio dan Loan to Deposit Ratio terhadap Return on assets. E-Journal Ekonomi dan Bisnis Universitas Bina Sarana Informatika. Volume 4 Nomor 2 Tahun 2016.

Budi, Ni Luh Putu., Wiagustini, dan ida bagus. 2017. Pengaruh kecukupan modal dan risiko kredit terhadap profitabilitas likuiditas sebagai pemediasi pada bank perkreditan rakyat di kabupaten badung. E-Jurnal Ekonomi dan Bisnis Universitas Udayana. Volume 6 Nomor 6 Tahun 2017.

Dewi, Ni Kadek Venimas, Wayan Cipta, dan I Ketut Kirya. 2015. Pengaruh LDR, LAR, DER dan CR Terhadap ROA. E- Journal Bisma Universitas Pendidikan Ganesha Jurusan Manajemen. Volume 3 Tahun 2015.

Frisca, Frisilia., Raisa Pratiwi. 2014. Pengaruh Good corporate governance,Likuiditas dan ukuran perusahaan terhadap profitabilitas pada Perusahaan BUMN yang termasuk dalam IICG dengan struktur modal sebagai variabel intervening. STIE Multi Data Palembang.

Hevy, Komang. 2019. Pengaruh Good Corporate Governance terhadap Profitabilitas Perbankan dengan Risiko Kredit sebagai Variabel Intervening (Pada Perbankan yang Terdaftar di BEI Periode 2014 -2016). Universitas Mataram. (e-ISSN: 2477-1767:vol7.no1- Maret-2019).

Ika Permatasari, Retno novitasary. 2013. Pengaruh Implementasi Good Corporate Governance terhadap Permodalan dan Kinerja Perbankan di Indonesia Manajemen Risiko sebagai Variabel Intervening. Universitas Negeri Surabaya.

Indah Dwi, Arief. 2015. Pengaruh Non Performing Loan (NPL) dan Capital Adequacy Ratio (CAR) terhadap profitabilitas. Universitas Negeri Semarang.

Kisman, Z. Model for Overcoming Decline in Credit Growth (Case Study of Indonesia With Time Series Data 2012m1-2016m12). Journal of internet Banking and Commerce.Vol.22,2017.

Kiswanto dan Asri Purwanti. 2016. Pengaruh Tingkat Kesehatan Bank menurut Risk Based Rating terhadap Kinerja Keuangan dengan Good Corporate Governance sebagai Variabel Intervening pada umum Syariah dan Unit Usaha Syariah di Indonesia. E-Jurnal Akuntansi Indonesia Universitas Unissula, Vol.5 No.1 2016.

Permatasari Ayu Nur, Dadan Rahadian dan Irni Yunita. 2017. Pengaruh CAR, LDR, BOPO,NPL dan Ukuran Perusahaan terhadap Profitabilitas (Studi Kasus pada Bank Umum Swasta dan Bank Devisa di Indonesia periode 2012 -2015). E-Procedding of Management Universitas Telkom: Vol.4 No.2 2017.

Pedoman Umum Good Corporate Governance Indonesia 2006.

Peraturan Bank Indonesia Nomor :. 13/1/PBI/2011 tentang Penilaian TingkatKesehatan Bank Umum.

Peraturan BI No. 8/14/PBI/2006 tentang PelaksanaanGood CorporateGovernance bagi Bank Umum.

Prinsip Dasar Pedoman Good Corporate Governance Perbankan Indonesia, diterbitkan oleh Komite Nasional Kebijakan Governance 
Restiyana. 2011. Analisis pengaruh CAR, NPL, BOPO, LDR, dan NIM terhadap Profitabilitas Perbankan. Universitas Diponegoro Semarang.

Riski Agustiningrum. 2018. Pengaruh antara Capital Adequay Ratio (CAR), Non performing Loan (NPL), Loan to Deposits Ratio (LDR). E-Jurnal Manajemen Universitas Udayana. Volume 2 Nomor 8 Tahun 2018.

Sandra, Kurniawati, Zilal Hamzah, dan Tri Kunawangsih. (2018). Analisis Pengaruh CAR, LDR, DER, BI Rate dan Inflasi Terhadap ROA Pada 10 Bank Besar di Bursa Efek Indonesia. Seminar Nasional Cendekiawan 4 Tahun 2018.

SE BI No. 13/24/DPND petunjuk pelaksanaan Peraturan BI No. 13/I/PBI.2011 25 Oktober 2011 Penilaian Tingkat kesehatan Bank Umum.

Sri Wahyuni Rasyid. 2012. Analisis Pengaruh Loan to Deposit ratio (LDR) Net interest margin (NIM) dan efisiensi terhadap return on assets (ROA) Bank Umum Indonesia. Universitas Hasanuddin.

Otoritas Jasa Keuangan, Booklet Perbankan Indonesia 2014. ISSN : 1858-4233 Departemen Perizinan dan Informasi Perbankan, , Edisi 1, Maret 2014. 